\title{
Market Orientation of Tribhuvan University Colleges
}

\author{
Sushil Awale*
}

DOI: https://doi.org/10.3126/jnbs.v13i1.34725

Accepted on 3 December 2020

\begin{abstract}
Tribhuvan University is the largest university in Nepal. The marketing of educational services is still a debatable issue in Nepal. This study analyzes the market orientation of Tribhuvan University's constituent colleges and affiliated colleges. The relationship among various dimensions of market orientation like customer focus, addressing student employer need, competition-oriented strategies, integration of organizational activities were examined and the impact of these dimensions was measured in terms of student satisfaction. This study is a quantitative causal analysis. Students of Tribhuvan University affiliated colleges were surveyed on the market orientation of the college. The study found that most of the colleges were not market-oriented. The study showed a positive correlation among student orientation, employer orientation and integrated activities. Further studies could analyze the market orientation of other Nepalese universities and the market orientation of particular faculty of the university.
\end{abstract}

Keywords: Competition oriented, customer satisfaction, employer orientation, integrated activities, market orientation

\section{INTRODUCTION}

Education is one of the basic services every human needs. Higher education is the final stage of formal learning that occurs after the completion of secondary education. The main institutions for higher education are universities. Universities transform people's lives and society as a whole through education, skill development and research. According to

\footnotetext{
* Mr. Awale is an Assistant Professor at the Central Department of Management, Tribhuvan University.

Email: bricksushil@gmail.com
} 
University Grant Commission Nepal (2017) there are nine fully autonomous non-private universities and four medical academies in Nepal. In the year 2015/16, there were altogether 1407 higher education campuses, 98 (6.97\%) constituent campuses, 777 (55.22\%) private and $532(37.81 \%)$ community campuses. In terms of the level of study 1270 campuses are offering Bachelor level programs and 258 campuses are offering Master level programs. In the year 2015/16, a total of 361,077 students were enrolled in Higher Education. Tribhuvan University has 284,453 (78.80\%) students, Pokhara University had 26,032 (7.20\%) students, Purbanchal University had 23,539 (6.51\%) students and Kathmandu University has 16,658 (4.61\%) students and the rest of the students were enrolled in other universities and medical academies. The share of student enrollment in the community campuses is 30.71 percent, constituent campuses are 33.72 percent, and private campuses are 35.57 percent.

Tribhuvan University, which was established in 1959, is the first university in Nepal. Tribhuvan University is a non-profit making autonomous institution funded by the Government of Nepal. Tribhuvan University is 6th largest in the world in terms of in-person enrollment of 604,437 students. It has 5 technical institutes and 4 general faculties, 4 research centers, 38 central departments, 62 constituent campuses and 1,084 affiliated colleges (Tribhuvan University, 2020).

Competition among the higher education service providers is growing day by day. Higher education institutions are relying on marketing to face the competition. There are issues like student politics, the launching of the semester system, late examination results, lack of linkage to management practitioners (Edmiston-Strasser, 2009; Gibbs, 2007; Khanna, Jacob, \& Yadav, 2014).

Marketing of educational services is very important. Marketing is customer-oriented therefore marketing is market orientation. Market orientation means companies delivering more values to the customer than their competitors through the integration of marketing activities throughout the company

The term market orientation is used to refer to the implementation of the marketing concept. Market orientation seeks to provide superior value relative to competitors for customers and other stakeholders such as students, employers of graduates, and parents of students, and seek to accomplish organizational goals (Kotler, Keller, Koshy, \& Jha, 2014; Oplatka \& Brown, 2007; Schlosser \& McNaughton, 2007).

According to the 2016 Open Doors Report on International Educational Exchange (IEE), a total of 9,662 Nepalese students enrolled for the academic year 2015-2016 for higher studies in US colleges and universities (Bista, 2018). According to the statistics at the Ministry of Education, 32,889 students have gone abroad to study in the year 2015/16, whereas 30,696 students went abroad in the year 2014/15. The number of students going abroad is increasing year by year. Students had spent NRS 17.065 billion in 2071/72 and 15.12 billion NRS in 2070/71 for their education abroad (Thapaliya, 2016). 
According to Koirala (2005) private educational institutions are unable to provide quality education to compete in the open markets. They teach with an exam-oriented mindset. Our higher education system has not yet been able to create a convincing link between educational degrees and jobs. Lack of motivation in teachers, slow service processes, inadequate management of the physical environment and resource centers are other hurdles in Nepalese universities (Chapagain \& Bhattarai, 2017; Flavian \& Lozano, 2006).

There is some empirical evidence from commercial and service sector organizations for the positive impact of market orientation on organizations (Silva \& Fernandes, 2012). The past research on marketing orientation found that it is positively correlated with innovation; business profitability; increased sales; high perceptions of service quality - excellence; employees' high levels of satisfaction and commitment; customers' satisfaction, and brand loyalty. Educational marketing has not paid sufficient attention to market orientation and explored its implications (Homburg, Grozdanovic, \& Klarmann, 2007; Oplatka \& Brown, 2007; Uprety \& Chhetri, 2014). The future of higher education institutions depends on their ability to attract and retain students. There is an abundance of study on the market orientation of foreign universities but not in Nepal. Therefore, this study has set two objectives. The first is to examine the relationship between various market orientation elements and student satisfaction. The second is to examine the effect of various market orientation elements on student satisfaction.

\section{LITERATURE REVIEW}

Marketing Orientation is the degree to which an organization generates and uses intelligence about the current and future needs of customers; develops a strategy to satisfy these needs; and implements that strategy to meet those needs and wants (Bunnell, 2005, Oplatka \& Brown, 2007). Zebal and Goodwin, (2012) found market orientation resulted in student growth, market share, teaching and service quality and overall performance of the private universities in Bangladesh. Siu and Wilson, (1998) propose four components: (1) Student orientation, (2) Employer orientation, (3) Competition orientation, and (4) Crossfunctional integration, to measure the market orientation of the university.

\subsection{Student Orientation}

In the case of higher education institution, a satisfied customer plays an important role in the promotion of that particular institution (Cameron \& Quinn, 1999; Deshpande \& Farley, 2004). Student satisfaction is a match between what students expect while entering colleges, and the perception and experiences they develop during the college years (Kotler, Keller, Koshy, \& Jha, 2014; Zeithaml, Bitner, Gremler, \& Pandit, 2011). According to William (2002), there is a new moral prerogative that students have become "customers" and therefore can, as fee payers, and student as co-producer of service, reasonably demand that 
their views be heard and acted upon (Armstrong, 2003; Morris, Coombes, Schindehutte, \& Allen, 2007; Svensson \& Wood, 2007). According to Shrestha (2013), school members are assumed to understand the school's target market thoroughly and be capable of creating and providing superior value, over time. A teacher who subscribes to this approach in practice would collect information about the environment in which his/her students lived (e.g. lifestyle factors) then changes teaching methods to accommodate students' particular needs, and would be attentive and responsive to parents' interests and points of view. Through this approach, it would then be possible to be more innovative and implement improvements for future students based on their anticipated needs.

\subsection{Employer Orientation}

Webster, Hammond, and Rothwell, (2010) in their study considered two customer groups studied were students and employers of students (Advance Collegiate Schools of Business, 2020). Their study found, as has previous research conducted on business organizations and within some educational organizations, that performance may be improved by increasing levels of market orientation. Focus on creating a market orientation culture should serve both schools and their various stakeholders, not just students, in more effectively achieving accounting department and business school objectives. Employer orientation will lead to the creation of students that employee desire and students getting job placement eventually satisfy students and parents (Noble, Sinha, \& Kumar, 2002).

\subsection{Competitor Orientation}

Awareness of the importance of competitor activity and the monitoring of developments in competing schools can have a positive impact on decision-making, particularly through the development of new initiatives: additional services for parents and students(Voss \& Voss, 2000; Webster et al., 2010).Competitor orientation, the second component of Marketing Orientation is often neglected in educational institutions, chiefly because educators sometimes perceive it to be incompatible with the moral values of education (Oplatka \& Brown, 2007).Universities compete for students and the restrictions on resources force them to act as corporations which must use strategies to compete in their markets (Bok, 2003; Veloutsou, Lewis, \& Paton, 2004).

\subsection{Cross-Functional Integration}

Attracting and sustaining students is the responsibility of everyone in the school community (Kotler et al., 2014). The third component of marketing orientation interfunctional integration encompasses the coordinated and integrated application of organizational resources to synthesize and disseminate market intelligence, in order to put processes in place to build and maintain strong relationships with customers (Oplatka \& Brown, 2007). Kuster and Aviles-Valenzuela (2010) in their study showed that Institutions (Campus) Marketing Orientation has a positive significant impact on the top Administration 
(Schools) Marketing Orientation but not on the teaching staff. Likewise, the top administration marketing orientation does not affect the teaching staff marketing orientation. However, teaching staff marketing orientation does impact job satisfaction.

\subsection{Conceptual Framework}

Based on the literature review and realized gap, the following conceptual framework is designed for the study.

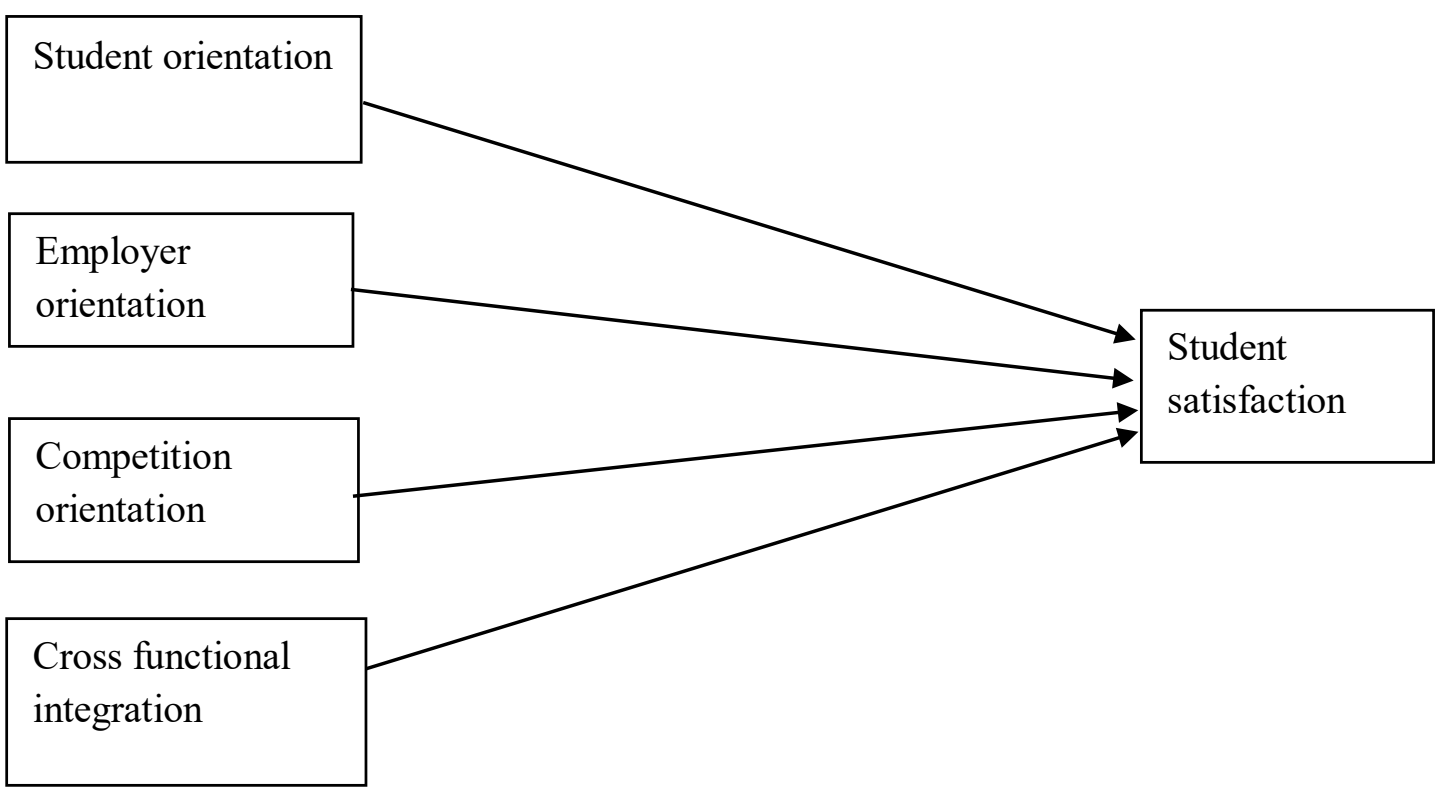

Figure 1. Schematic diagram of the conceptual framework.

In this framework student orientation, employer orientation, competition orientation, cross functional integration are independent variables and student satisfaction is dependent variable.

Market orientation: Market orientation means organization fulfilling customers' need better than its competitors. The term market orientation is used to refer to the implementation of the marketing concept (McCarthy \& Perreault, 1984).

Cross functional integration: Cross functional integration means coordination among all department and activities of the college

Student orientation: Student orientation means organization focusing on students' requirement. 
Employer orientation: Employer orientation means organization addressing the requirements of the graduate student employer.

Competition orientation: Competition orientation means college fulfilling the gaps that competitors could not fulfill regarding customer needs.

Student Satisfaction: Student satisfaction means student liking of the college and students recommending the college to other students.

\section{METHODOLOGY}

This study is a quantitative causal analysis based on the study designs of Chaudhry, Mahesar, Ansariand Ali (2016), Niculescu, Xu, Hampton and Peterson (2013), RiveraCamino and Ayala (2010), and Siu and Wilson (1998). Students of Tribhuvan University affiliated colleges were surveyed on the market orientation of the college. This study is based on primary data. Market orientation among Tribhuvan University colleges was measured through a questionnaire. The result by the characteristic of the college (public/private/community, bachelor/master level) was analyzed.

Convenience and quota sampling is applied to select colleges. Out of six selected colleges, two were public colleges, two were private colleges and two were community colleges. Seventy students from each college were selected for inquiry. A sample size of 386 was determined based on the table of Cochran (1977). A total of 425 questionnaires were distributed. Fully filled 398 questionnaires were recovered from the respondent for analysis. Correlation and regression tools were used for analysis.

Colleges were visited based on appointments provided by principals. Students were briefed on the type of research and how it will benefit students and stakeholders. The questionnaire was distributed to interested students. The questionnaire was collected after fillup on the spot.

\section{RESULTS}

After collection, processing and analysis of data following results were found. The respondent profile is the demographic description of the respondent of this study. Respondents' profile is summarized in Table 1. The table shows most of the respondents are from constituent colleges of the university, are studying bachelor's level, and are female. Descriptive analysis of the data revealed the measures of central tendency which are presented in Table 2. 
Table 1

Respondents Profile

\begin{tabular}{llcc}
\hline Items & Description & Frequency & Percentage \\
\hline \multirow{3}{*}{ Category of college } & Constituent & 228 & 57.3 \\
& Community & 85 & 21.4 \\
& Private & 85 & 21.4 \\
\hline \multirow{2}{*}{ Academic level } & Bachelor & 228 & 57.3 \\
& Master & 170 & 42.7 \\
\hline \multirow{2}{*}{ Gender } & Male & 143 & 35.9 \\
& Female & 255 & 64.1 \\
\hline
\end{tabular}

Questionnaires were prepared on five points Likert scale. Table 2 shows colleges' mean score on student orientation is highest and colleges' mean score on competitor orientation is lowest among the measured variables. The outputs show the data are about symmetric as the values for skewness and kurtosis between -1.96 and +1.96 are considered acceptable in order to prove normal univariate distribution.

Table 2

Descriptive Statistics for all Samples

\begin{tabular}{|c|c|c|c|c|c|c|c|}
\hline $\begin{array}{l}\text { Variable/ } \\
\text { Statistic }\end{array}$ & $\mathrm{N}$ & Mean & SEM & STD & Skewness & SES & Range \\
\hline $\mathrm{SO}$ & 398 & 3.457 & 0.020 & 0.398 & -0.930 & 0.122 & 2.76 \\
\hline EO & 398 & 2.802 & 0.019 & 0.388 & 0.352 & 0.122 & 1.25 \\
\hline $\mathrm{CO}$ & 398 & 2.427 & 0.041 & 0.821 & 0.451 & 0.122 & 2.00 \\
\hline CFI & 398 & 2.745 & 0.033 & 0.662 & 1.020 & 0.122 & 2.77 \\
\hline SS & 398 & 3.854 & 0.018 & 0.353 & -2.016 & 0.122 & 1.00 \\
\hline
\end{tabular}

If there is no correlation between dependent and independent variables, the impact of independent variables on a dependent variable will not be valid therefore before measuring the impact of independent variables correlation between the variables must be confirmed. Correlation between the dependent variable and independent variables are presented in Table 3. The table shows a perfect correlation between employer orientation and competition orientation. The study shows moderate correlations between student orientation and employer orientation, between student orientation and competition orientation, between employer orientation and cross-functional integration, between competition orientation and crossfunctional integration, between cross-functional integration and student satisfaction. 
Table 3

\section{Pearson Correlations}

\begin{tabular}{|c|c|c|c|c|c|}
\hline Variables & SO & EO & $\mathrm{CO}$ & CFI & $\mathrm{SS}$ \\
\hline SO & 1 & & & & \\
\hline $\mathrm{EO}$ & $\begin{array}{l}.481 * * \\
(0.001)\end{array}$ & 1 & & & \\
\hline $\mathrm{CO}$ & $\begin{array}{l}.528 * * \\
(0.001)\end{array}$ & $\begin{array}{l}.908 * * \\
(0.001)\end{array}$ & 1 & & \\
\hline CFI & $\begin{array}{c}0.080 \\
(0.113)\end{array}$ & $\begin{array}{l}.558 * * \\
(0.001)\end{array}$ & $\begin{array}{l}.575 * * \\
(0.001)\end{array}$ & 1 & \\
\hline $\mathrm{SS}$ & $\begin{array}{l}0.105 * \\
(0.023)\end{array}$ & $\begin{array}{l}.322 * * \\
(0.001)\end{array}$ & $\begin{array}{l}.215 * * \\
(0.001)\end{array}$ & $\begin{array}{c}.466 * * \\
(0.001 \\
)\end{array}$ & 1 \\
\hline
\end{tabular}

Note. Figures in parentheses are p-values. The asterisk signs $\left({ }^{* *}\right)$ and $(*)$ indicate that the results are significant at 1 percent and 5 percent level respectively.

The study found there are low correlations between employer orientation and student satisfaction, between competition orientation and student satisfaction, between student orientation and student satisfaction. In Table 3 significant correlation between dependent and independent variables qualifies for the measurement of the impact of independent variables on the dependent variable. Table 4 illustrates the impact of the independent variable.

Table 4

Regression Analysis

\begin{tabular}{lcccccc}
\hline Variables & Beta coefficient & Std. Error & $\mathrm{t}$ & Sig. & $\mathrm{R} 2$ & $\mathrm{~F}$ \\
& 1.93 & 0.222 & 8.711 & 0.000 & & \\
(Constant) & 0.096 & 0.047 & 2.046 & 0.041 & & \\
SO & 0.559 & 0.093 & 6.041 & 0.000 & & \\
EO & -0.299 & 0.047 & -6.402 & 0.000 & & \\
CO & 0.274 & 0.029 & 9.34 & 0.000 & & \\
CFI & & & & & 0.296 & 41.29 \\
& & & & & & $(0.001)$ \\
\hline
\end{tabular}

Table 4 shows the effect of all dependent variables is significant and positive except the effect of competitor orientation was negative on student satisfaction. The study showed employee orientation had the highest contribution to student satisfaction. The data fits the model well as the $\mathrm{F}$ value is also significant at 0.01 level of significance. The model shows independent variables explain a 30\% change in the dependent variable as R square is 0.296 . 


\section{DISCUSSION}

The high score found in this study for the student orientation of colleges is in line with customer orientation of marketing theory (Kotler et al., 2013). Students are the customers for the college (William, 2002). The study also showed a higher mean score of 3.9 regarding student satisfaction. This is obvious because colleges are growing day by day; supply is higher than demand in the education sector; a satisfied student is a must for the survival of the college (University Grant Commission Nepal, 2017). The majority of the respondent of this study belong to either a university-affiliated campus or a community campus. Fees are very low in these colleges compared to private colleges. Nepalese customers are motivated by low cost. Price appeal in advertising is more effective in Nepal (Agrawal, 2014; Koirala, 2011; Thapa \& Awale, 2016).

A perfect correlation between employer orientation and competition orientation can be discussed with two schools of thought in the marketing of educational services (Awale, 2011; Kotler et al., 2014). The traditional school of thought says that education should not be commercialized and marketing of education is wrong. Another school of thought advocates marketing is a must in every sector even in the nonprofit sector. Colleges that believe in the marketing of educational service will market their service, they tend to use all marketing tools; they are market-orientated. Colleges that are market-oriented are oriented toward employers and competitors both. There is the trend of signing MOU with the business organization as well as with partner institutions. Marketing-oriented colleges are the concern of other organizations (Cravens \& Piercy, 2010; Shrestha, 2013). Both competitors and employers are organizations. Organizations that are concern about other organizations' activities are concern with employer organizations as well as other educational organizations (competitors).

After taking the educational service student getting the job is very important. Colleges that are employee-oriented have linkage and MOU with many employer organizations which makes college students' job placement easy, this results in student satisfaction. (Shrestha, 2013; Zeithaml et al., 2011). This study also showed employer orientation had the highest contribution to student satisfaction. Technical quality of service is the outcome of service (Gronroos, 2007). Customers have a higher regard for the market leaders. The college that only follows others instead of innovation and creativity are regarded as inferior by students (Kotler et al., 2014). Maybe due to this reason, this study showed competitor orientation has a negative effect on student satisfaction.

\section{CONCLUSIONS}

Market orientations of Tribhuvan University's colleges are growing. Tribhuvan University's affiliated colleges are moderately student-oriented and students are moderately 
satisfied. There is a lack of competitor orientation among Tribhuvan University affiliated colleges. Employer orientation in college contributes the highest to student satisfaction.

The study has shown market orientation increasing student satisfaction therefore colleges must be market-oriented. Among the dimensions of market orientation there is a lack of employer orientation, competitor orientation, cross-functional integration therefore these dimensions should be considered for improvement. Regression model showed students' employer orientation has the highest contribution to student satisfaction. Therefore, colleges must develop a curriculum that suits employers. Colleges must develop a linkage with the corporate houses. Colleges must accommodate practitioners as faculties. Causes of negative contribution to market orientation can be analyzed in further studies.

\section{REFERENCES}

Agrawal, G. R. (2014). Marketing communication. Kathmandu: M. K. Publishers.

Armstrong, M. (2003). Students as clients: A professional services model for business education. Academy of Management Learning \& Education, 2, 371-374.

Advance Collegiate Schools of Business (2020, February 11). AACSB's Accreditation Quality Management System Achieves. Retrieved fromwww.aacsb.edu

Awale, S. (2011). Brick marketing in Kathmandu. Pravaha: Journal of Management, 17(17), 121-126.

Bista, K. (2018). Role of intermediary recruiters in higher education preparation: Perceptions of Nepalese students in the United States. Journal of International and Global Studies, 9(1), 93-111.

Bok, D. (2003). Universities in the marketplace: The commercialization of higher education. Princeton: Princeton University Press.

Bunnell, T. (2005). Strategic marketing planning in international schools. International Journal of Educational Management, 19(1), 9-66.

Cameron, K., \& Quinn, R. (1999). Diagnosing and changing organizational culture. Reading, MA: Addison-Wesley.

Chapagain A., \& Bhattarai, B. (2017 November 27). Studying abroad. The Himalayan Times. Retrieved from www.thehimalayantimes.com

Chaudhry, N. I., Mahesar, H. A. Ansari, M. A., \& Ali, M. (2016). Impact of market orientation on the performance of private universities in Pakistan. International Research Journal of Arts \& Humanities, 44(1), 21-32.

Cochran, W. G. (1977). Sampling techniques. New York: John Wiley \& Sons.

Cravens, D. W., \& Piercy N.F. (2010). Strategic marketing. Illinois: Irwin.

Deshpande, R., \& Farley, J. U. (2004). Organizational culture, market orientation, innovativeness and firm performance. International Journal of Research in Marketing, 22, 3-22. 
Edmiston-Strasser, D. M. (2009). An examination of integrated marketing communication in U.S. public institutions of higher education. Journal of Marketing for Higher Education, 19(2), 142-165.

Flavian, C., \& Lozano, J. (2006). Organizational antecedents of market orientation in the public university system. International Journal of Public Sector Management, 19(5), 447-467.

Gibbs, P. (2007). Does advertising pervert higher education? Is there a case for resistance? Journal of Marketing for Higher Education, 17(1), 3-11.

Gronroos, C. (2007). Service management and marketing. New Delhi: Wiley.

Homburg, C., Grozdanovic, M., \& Klarmann, M. (2007). Responsiveness to customers and competitors: The role of affective and cognitive organizational systems. Journal of Marketing, 71, 8-38.

Khanna, M., Jacob, I. C., \& Yadav, N. (2014). Identifying and analyzing touch points for building a higher education brand. Journal of Marketing for Higher Education, 24(1), 122-143.

Koirala, K. D. (2011). Advertising. Kathmandu: Buddha Academic Publishers.

Koirala, P. (2005). Vision and mission of management education in Nepal. Tribhuvan University Journal, 25(1), 27-32.

Kotler, P., Keller K. L., Koshy A., \& Jha, M. (2014). Marketing management. New Delhi: Pearson Education.

Kuster, I., \& Aviles-Valenzuela, M.E., (2010). Market orientation in university: A case study. International journal of educational management, 24 (7), 597-614.

McCarthy J. E., \& Perreault, W. D. (1984). Basic marketing: A managerial approach. Toronto: Irwin.

Morris, M., Coombes, S., Schindehutte, M., \& Allen, J. (2007). Antecedents and outcomes of entrepreneurial and market orientations in a non-profit context: Theoretical and empirical insights. Journal of Leadership \& Organizational Studies, 13(4), 12-39.

Niculescu, M., Xu, B., Hampton, G. M., \& Peterson, R. T. (2013). Market Orientation and its Measurement in Universities. Administrative Issues Journal, 3(2), 72-87.

Noble, C. H., Sinha, R. K., \& Kumar, A. (2002). Market orientation and alternative strategic orientations: A longitudinal assessment of performance implications. Journal of Marketing, 66, 25-39.

Oplatka, I., \& Brown, J. H. (2007). The incorporation of market orientation in the school culture: An essential aspect of school marketing. International Journal of Educational Management, 21(4), 292-305.

Rivera-Camino, J., \& Ayala, V. M. (2010). Market orientation at universities construct and exploratory validation. Innovar Journal, 20(36), 125-138. 
Schlosser, F., \& McNaughton, R. (2007). Internal stakeholder views of a market orientation strategy: Implications for implementation. Journal of Strategic Marketing, 15(4), 307-325.

Shrestha, B. K. (2013). Public perception of the quality of academic education program. Journal of Education and Research, 3(1), 52-64.

Silva, F., \& Fernandes, P. O. (2012). Empirical study on the student satisfaction in higher education: Importance-satisfaction analysis. World Academy of Science, Engineering and Technology, 6(6), 1192-1197.

Siu, N., \& Wilson, R. (1998). Modelling market orientation: An application in the education sector. Journal of Marketing Management, 14(4), 293-323.

Svensson, G., \& Wood, G. (2007). Are university students really customers? When illusion may lead to delusion for all. International Journal of Educational Management, 21(1), 17-28.

Thapa, G., \& Awale, S., (2016). Television watching habits of children in Kathmandu. DAV Research Journal, 1(1), 70-73.

Thapaliya, R. (2016, April 2). Nepalese student's struggle and difficulties in the USA. Retrieved from www.huffingtonpost.com

Tribhuvan University (2020 July 25). About us. Retrieved from www.tribhuvanuniversity.edu.np

University Grant Commission (2017). Education management information system. Retrieved from www.ugcnepal.edu.np

Uprety, R., \& Chhetri, S. B. (2014) College culture and student satisfaction. Journal of Education and Research, 4(1), 77-92.

Veloutsou, C., Lewis, J., \& Paton, R. (2004). University selection: Information requirements and importance. International Journal of Educational Management, 18(3), 160-171.

Voss, G., \& Voss, Z. (2000). Strategic orientation and firm performance in an artistic environment. Journal of Marketing, 64(1), 67-83.

Webster, R. L., Hammond, K.L., \& Rothwell, J.C. (2010). Customer and market orientation within AACSB member business schools: Comparative views from three levels of administrators. American Journal of Business Education, 3(7),79-92.

William, J. (2002). The student satisfaction approach: Student feedback and its potential role in quality assessment and enhancement. Paper presented at the 24th EAIR Forum, 811September, Prague, The Czech Republic.

Zebal, M.A., \& Goodwin, D.R. (2012). Market orientation and performance in private universities. Marketing Intelligence \& Planning, 30(3), 339-357.

Zeithaml, V. A., Bitner, M. J., Gremler, D. D., \& Pandit, A. (2011). Services marketing. New Delhi: Tata McGraw-Hill. 